Politics and Governance (ISSN: 2183-2463)

2017, Volume 5, Issue 3, Pages 6-15

DOI: 10.17645/pag.v5i3.985

Article

\title{
Secrecy, Efficiency, Transparency in EU Negotiations: Conflicting Paradigms?
}

\author{
Päivi Leino \\ UEF Law School, University of Eastern Finland, FI-80101 Joensuu, Finland; E-Mail: paivi.leino@helsinki.fi
}

Submitted: 4 May 2017 | Accepted: 11 September 2017 | Published: 25 September 2017

\begin{abstract}
This contribution considers how the values of transparency and efficiency are realised in the context of "EU negotiations" both in the internal and the external sphere. Legislating comes with a presumption of openness in the EU, while international negotiations have traditionally been assumed to require secrecy. However, irrespective of the basic paradigms, the institutions often appear to follow a rather simple rationale that secrecy makes better decisions, both in internal and external affairs. Similar efficiency concerns seem to relate to protecting the procedure of decision-making from external influence. Therefore, the fundamental trade-off between democratic accountability and efficiency in the external and internal fields might not be all that different: efficiency is linked with secrecy, and comes at a cost for participation and openness. I explain how the two paradigms-openness and transparency in legislative work and secrecy in international negotiations have recently developed, and how the values of openness and efficiency have been addressed by the Court of Justice of the European Union in its recent jurisprudence. This discussion witnesses to a possibility that the old secrecy paradigm might be about to break in international relations while a new transparency paradigm in EU legislative work is struggling to emerge.
\end{abstract}

\section{Keywords}

EU; international relations; negotiations; secrecy; transparency

\section{Issue}

This article is part of the issue "EU Institutional Politics of Secrecy and Transparency in Foreign Affairs", edited by Vigjilenca Abazi and Johan Adriaensen (Maastricht University, The Netherlands).

(C) 2017 by the author; licensee Cogitatio (Lisbon, Portugal). This article is licensed under a Creative Commons Attribution 4.0 International License (CC BY).

\section{Introduction}

The 2001 Laeken Declaration, adopted by the European Council to guide the reform of the EU Treaties, illustrates a vision for Europe. It stresses how the EU institutions must be brought closer to citizens, and become more efficient and more open. According to the Declaration, citizens feel that "deals are all too often cut out of their sight and they want better democratic scrutiny" and wish to see a Europe that is "democratic and globally engaged" (European Council, 2001). The Lisbon Treaty, which entered into force in 2009, attempts to meet these expectations but leaves much institutional discretion in the application of these objectives. The question is not so much about whether the EU should be "open", "efficient" or "democratically and globally engaged" - of course the EU should be all of these things. But when legislative guidance is limited or outdated, the balance between these objectives is in practice drawn by the institutions when they are addressing appeals by individuals seeking access to individual documents. This paper questions whether this balance is currently the right one.

In institutional attitudes, efficiency often takes priority over other values such as openness or participation and results in secrecy rather than transparency (see Leino, 2014). As the European Ombudsman has noted, "there is an inevitable tension between the very laudable principles of public consultation and participation, and the requirements of efficient law making" (European Ombudsman, 2015, para. 44). The general function of transparency and openness in EU decisionmaking is defined in the preamble of Regulation No 
$1049 / 2001$ on public access to documents with reference to how it:

enables citizens to participate more closely in the decision-making process and guarantees that the administration enjoys greater legitimacy and is more effective and more accountable to the citizen in a democratic system. Openness contributes to strengthening the principles of democracy and respect for fundamental rights....

According to this quote, transparency's function is seen to apply to all kinds of decision-making, both legislative and executive in nature. Efficiency is usually understood in terms of the ability to make compromises, the number of decisions adopted and the ability to implement the measures that have been adopted (see Novak, 2011). As Advocate General Cruz Villalón recently put it:

Inconvenient though transparency may be...it has never been claimed that democracy made legislation "easier", if easy is taken to mean "hidden from public scrutiny", as public scrutiny places serious constraints on those involved in legislating. (Council v. Access Info Europe, 2013, para. 67)

In this contribution, I will look at how the values of transparency and efficiency are realised in the context of "EU negotiations", both in the internal sphere (legislating) and the external sphere (international negotiations, largely an executive function). ${ }^{1}$ Legislating comes with a presumption of openness in the EU, while international negotiations have traditionally been assumed to require secrecy. However, irrespective of the field of action and the basic paradigms applicable to them, the institutions often appear to follow a rather simple rationale that secrecy leads to better decisions, both in internal and external affairs (Curtin, 2012, p. 471). Similar efficiency concerns seem to relate to protecting the procedure of decision-making from external influence. Therefore, the fundamental trade-off between democratic accountability and efficiency in the external and internal fields might not be all that different: efficiency is linked with secrecy, and comes at a cost for participation and openness.

In the following, I will explain how the two paradigms-openness and transparency in legislative work and secrecy in international negotiations-have recently developed, and how the values of openness and efficiency have been addressed by the CJEU in its recent jurisprudence, which can be seen as a sort of "game changer" (see Abazi \& Hillebrandt, 2015, p. 825). This discussion reveals a possibility that the old secrecy paradigm might be about to break in international relations while a new transparency paradigm in EU legislative work is struggling to emerge.

\section{Two Opposite Paradigms: Secrecy and Transparency}

Secrecy in the area of international relations has been an exceptionally strong paradigm (see Leino, in press). Foreign affairs have been traditionally characterised by secret deals and treaties (Macmillan, 2011). The security paradigm in international relations dates back to a time when it was a much more exotic business than it is today. Secrets were primarily stolen for tactical reasons, in order to buttress national secrecy or political advantage, and not only for the interest of a general "right to know".

A strong secrecy paradigm is also built into the EU public access regime. The most relevant exception for international relations is included in Article 4(1)(a) of Regulation 1049/2001, which establishes that:

The institutions shall refuse access to a document where disclosure would undermine the protection of...the public interest as regards...international relations.

It is a broadly defined exception, which not only increases discretion at the stage of deciding on public access but also the role of Courts in settling how the exception is to be interpreted.

Unlike the exceptions under Article 4(2) of the Regulation, the exceptions under Article 4(1) include no "public interest" test, which requires the institution to consider whether access should be granted despite the fact that its disclosure would be likely to cause harm. The Court has stressed that the "particularly sensitive and essential nature of the interests protected" under this exception and its mandatory nature confers on decisions on public access "a complex and delicate nature which calls for the exercise of particular care. Such a decision requires, therefore, a 'margin of appreciation'" (Sison $v$. Council, 2007, para. 35). Even a nominal reasoning can be adequate if otherwise sensitive interests would be harmed through disclosure of the very information that the exception is designed to protect (Sison v. Council, 2007, paras. 81-83). The way the CJEU has interpreted the exception has strengthened the understanding that international relations are hard to conduct in public, and that they should, as the main rule, remain confidential. A similar paradigm also exists in most national Freedom of Information (public access) systems. ${ }^{2}$

As far as legislative negotiations among EU states are concerned, the paradigm is the opposite. Since the

\footnotetext{
${ }^{1}$ Defining what exactly counts as "executive power" in the EU has often relied on a "residual" approach, treating executive power as the power that is not judicial or legislative in nature, i.e. as the power that is not exercised by anyone else (see Curtin, 2009, p. 53). The negotiation and conclusion of international agreements is an executive function that is neither legislative nor judicial in nature.

2 For example, in the rather liberal Finnish system, documents relating to the conduct of foreign relations are secret, unless otherwise decided, see Act on the Openness of Government Activities, 1999, section 24. In the relevant government proposal, this secrecy regime is justified with reference to how only very few countries follow the principle of openness and, in addition, the international practice is that negotiating parties' statements and positions are not released without their consent, and that states follow each other's' confidentiality rules.
} 
Treaty of Lisbon, EU legislative work should take place in the open (Article 15 TFEU). Regulation No 1049/2001 acknowledges the need to grant even "wider access" to "documents in cases where the institutions are acting in their legislative capacity...while at the same time preserving the effectiveness of the institutions' decisionmaking process". Legislative documents are defined as those that relate to procedures resulting in legally binding acts in or for the Member States. This condition certainly applies to many international agreements as well, but has so far received no attention by the Court. The provisions relating to legislative matters have been subject to the Court's landmark ruling in Turco, which stresses how increased openness

enables citizens to participate more closely in the decision-making process and guarantees that the administration enjoys greater legitimacy and is more effective and more accountable to the citizen in a democratic system. Those considerations are clearly of particular relevance where the Council is acting in its legislative capacity.... Openness in that respect contributes to strengthening democracy by allowing citizens to scrutinize all the information which has formed the basis of a legislative act. The possibility for citizens to find out the considerations underpinning legislative action is a precondition for the effective exercise of their democratic rights. (Kingdom of Sweden and Maurizio Turco v. Council, 2008, paras. 45-46)

The Lisbon principles relating to transparency specifically aim at creating a paradigm shift through an explicit acknowledgement that EU legislative work should no longer to be understood as a traditional, secretive diplomatic process (e.g. Westlake \& Galloway, 2004, pp. 372-373).

The application of two different paradigms presumes that a distinction could be usefully made between what is "internal" and what is "external". This is hardly the case today. Internal logics of legislation seep into external negotiations and vice versa. Internal legislative activity has a strong international dimension. Not only are many important external measures based on "internal" policy competences (e.g. environmental policy) via the doctrine of implied external powers; today, internal legislative activity has a strong international dimension (European Commission, 2015b). The EU frequently uses legislative techniques with territorial extension and exercises global regulatory power through EU legislation (the "Brussels Effect") (see Bradford, 2012; Scott, 2014, p. 87 et seq;). The Commission has recently made a point of how "virtually all Internal Market policies carry to some degree an 'international dimension"' and require "adequate and consistent consideration" and in all other international fora "to adequately represent and promote the principles of the European Internal Market in the world" (European Commission, 2015b). In fact, many situations that in the classic internal-external dichotomy fall under "internal" activities, because they are largely based on EU legislation, deal with third states, international organisations, or citizens or companies of third states (see e.g. Scott, 2014). The interest of foreign diplomats stationed in the EU is focused more on influencing the EU legislative procedure than on secret international treaty negotiations in the classic sense. For example, a report relating to US influence in the adoption of the REACH legislation demonstrates how US diplomatic posts were directed to influencing future EU chemicals policy, and concludes with a finding that the US efforts brought about significant concessions in the draft (Waxman, 2004). This illustrates how post-Lisbon, as far as legislative matters are concerned, life should be easy for the simple spy: most stages of the process should take place in the open.

The exception that is of greatest relevance for efficiency concerns is Article 4(3) of Regulation 1049/2001, the "space to think" exception:

Access to a document, drawn up by an institution for internal use or received by an institution, which relates to a matter where the decision has not been taken by the institution, shall be refused if disclosure of the document would seriously undermine the institution's decision-making process, unless there is an overriding public interest in disclosure.

Article 4(3) is the exception primarily invoked by the institutions when they wish to protect the efficiency of their functioning (the lead case in this regard is Verein für Konsumenteninformation v. Commission, 2005, para. 112). ${ }^{3}$ It is often relied on in addition to a substantive one in Article 4(1) and (2). Denials of access are thus based both on the substance of the document and the stage of decision-making, if no final decision has yet been taken on the matter. However, there would seem to be at least two exceptions to this practice. First, in legislative matters Article 4(3) has also been invoked alone (see most notably Council v. Access Info Europe, 2013, where the Council relied on one exception ground only, that being the first paragraph of Article 4(3)). Second, when a matter falls substantively under the international relations exception, the institutions would seem to refrain from invoking Article 4(3) irrespective of whether they are protecting their own internal decision-making stage or the actual negotiating procedure with third states (see below). The explanation for this institutional practice is simple: the public interest test that would then become applicable in matters falling under international relations, where potential public interest in gaining access can otherwise be ignored.

\section{Internal Logics in External Negotiations}

The internal-external dichotomy described above is particularly questionable in the context of international reg-

\footnotetext{
$\overline{3}$ I have discussed this case law in Leino (2011).
} 
ulatory agreements that have a direct impact on individuals and their rights. Many key aspects of our daily life depend on rules and decisions adopted at international level, later to be adopted into EU law (on this, see Mendes, 2015). Despite these developments, postLisbon case law has emphasised the formal division between legislative and non-legislative documents (Curtin \& Leino, 2016). The most crucial question in determining the scope of public access has therefore become whether the documents relate to a legislative procedure. In this case, the openness paradigm should in principle apply, even though this is something with which the institutions are struggling (Leino, 2014). In practice, the distinction between legislative and non-legislative is rather artificial and does not reflect the realities of EU decisionmaking, where many procedures do not fall clearly under either of these two categories (see Curtin \& Leino, 2016; see also ClientEarth v. Commission, 2015; Schlyter v. Commission, 2015). The openness paradigm has also offered the institutions an excuse to argue that if a document does not relate to a legislative procedure-which is the case with many documents relating to international relations - then the principle of openness has less relevance. It is the recent jurisprudence and other events relating to topical international negotiations that we turn to next.

\subsection{Case Law}

There are currently three lead cases from the European Courts that discuss transparency in the context of "new" types of international agreements. The first case, which was brought by Sophie in 't Veld MEP under the public access rules, concerned a Council Legal Service opinion on the proposed legal basis of the draft Council decision to authorise the Commission to launch negotiations for the so-called SWIFT Agreement (Sophie in 't Veld v. Council, 2012). In 't Veld had received partial access, with the Council invoking the exceptions relating to the protection of international relations and legal advice. While the latter exception brought in the "public interest" test, its application was difficult to avoid when the matter concerned a legal service opinion, which the Council was reluctant to disclose. It argued that disclosure would not only reveal information on certain provisions in the envisaged Agreement but also have a negative impact on the EU negotiating position and damage the climate of confidence. The legal basis issue was sensitive, since it had an impact on the Parliament's prerogatives, and was subject to disagreement between the institutions. In those circumstances, the Council felt that disclosure of an internal opinion of the Legal Service, intended only for preliminary discussions among the delegations, would be detrimental, and something that outweighed the public interest in disclosure (paras. 10 and 15 of the contested Council decision; see Sophie in 't Veld v. Council, 2012, para. 7). The matter was first dealt with by the General Court and then, following Council appeal, by the CJEU.
A key issue in these rulings concerned the substance of the envisaged agreement and its close connection with EU legislative activity. Advocate General Sharpston stressed that whether an institution acts in a legislative, executive or administrative capacity should not be determinative. What should be decisive is the need to conduct a careful and objective assessment and provide detailed and specific reasoning (Council v. Sophie in 't Veld, 2014, para. 98). The CJEU did not adopt this reasoning, but still stressed that the principle of transparency applies to decision-making in the field of EU international activity (Council v. Sophie in ' $t$ Veld, 2014, para. 76). It acknowledged that the considerations relating to citizen participation and the legitimacy of administration are of a particular relevance where the Council is acting in its legislative capacity. However, the General Court also pointed out that the matter concerned an international agreement with potential implications for EU legislative activity and the protection of personal data, which is a fundamental right (Sophie in 't Veld v. Council, 2012, paras. 89, 92). The General Court also considered the effect of the on-going procedure for concluding the international agreement and established that

Indeed, the public interest in the transparency of the decision-making process would become meaningless if, as the Commission proposes, it were to be taken into account only in those cases where the decisionmaking process has come to an end. (Sophie in 't Veld v. Council, 2012, para. 101)

The Court accepted the non-disclosure of those elements in the document that could reveal the strategic objectives pursued by the EU in the negotiations. Outside of those parts, the Council had not demonstrated how, "specifically and actually", harm to the public interest in the field of international relations existed (Council v. Sophie in 't Veld, 2014, para. 46). The ruling clearly evidences a much less categorical approach to the exception than the one found in its previous jurisprudence ( $\mathrm{Si}$ son v. Council, 2007).

The second case brought by Ms in 't Veld concerned a Commission decision to refuse access to a number of documents relating to the famous draft international AntiCounterfeiting Trade Agreement (ACTA) produced during the negotiations between the parties (Sophie in ' $t$ Veld $v$. Commission, 2013). The General Court here proved more responsive to the Commission concerns. It emphasised the "particularly sensitive and essential nature of the interests" relating to international relations, which gives the decisions on access "a complex and delicate nature which calls for the exercise of particular care" and presumes "some discretion" (Sophie in 't Veld v. Commission, 2013, para. 108). It noted that EU positions naturally change during negotiations, depending on concessions and compromises made by others, and accepted that "the formulation of negotiating positions may involve a number of tactical considerations of the nego- 
tiators, including the European Union itself" (Sophie in 't Veld v. Commission, 2013, para. 125). Unilateral disclosure of EU negotiating positions might have negative effects and seriously undermine the maintenance of mutual trust, which is essential to the effectiveness of negotiations and a very delicate exercise (Sophie in ' $t$ Veld $v$. Commission, 2013, paras. 125-126). Finally, since the international relations exception was mandatory and thus involved no public interest test, arguments based on an overriding public interest were rejected as "ineffective" (Sophie in 't Veld v. Commission, 2013, para. 131). Overall, the Court proved sensitive to considerations relating to the need to protect EU strategic objectives and the climate of negotiations.

The ACTA story has been mostly discussed from the point of view of the European Parliament (EP) defending the right to know and hold the Commission and Council accountable for their actions, reflected later in its refusal to give its consent to the conclusion of the agreement. But the EP's own transparency policy in relation to the negotiations has also been scrutinised by the European Ombudsman following complaints by 28 digital civil rights associations (European Ombudsman, 2013). They claimed that in refusing to grant full access to the negotiation documents that the EP had in its possession, largely received from the Commission based on the Framework Agreement between the two institutions (European Parliament \& European Commission, 2010), it failed to act in line with the legitimate and reasonable expectation that the EP would live up to its past declarations on transparency in the ACTA process (European Parliament, 2010). In the context of the Ombudsman investigation, the EP line of defence closely followed that taken by the Council and Commission in other cases, which it had strongly criticised. The Ombudsman found no maladministration on the Parliament's part. The Ombudsman expressed an understanding for the difficulties involved in revealing negotiating positions of other parties:

releasing the documents in question, which reveal the negotiating position of the US and Japan, would be highly likely to be detrimental to the EU's relations with those countries....It is likely that such disclosure would have a negative effect on the climate of confidence in the on-going negotiations, and that it would hamper open and constructive co-operation. (European Ombudsman, 2010, para. 33)

A particular characteristic of the ACTA case related to the agreement among the various negotiating partners that matters would remain confidential, the question then being whether the Commission in fact had the right to consent to such a solution, keeping in mind its transparency obligations under the Treaties. This issue was raised both before the General Court and the European Ombudsman. The Court did not address the appropriateness of confidentiality agreements, but accepted that the Commission's refusal had been correctly based on Article 4(1)(a).
The Ombudsman was more critical and found that "serious consideration should be given by any EU body that makes such a commitment to ensure that it does not undermine the principles essential to a democratic EU that underpin the Turco case-law" (European Ombudsman, 2013, para. 62).

The third recent case was brought by Professor Besselink and concerned the draft Council Decision on a negotiating mandate authorising the Commission to negotiate the EU Accession Agreement to the European Convention of Human Rights (Leonard Besselink v. Council, 2013). The Court found that the Council had interpreted the international relations exception too broadly, and stressed that it could only be used to protect objectives that were subject to concrete negotiations. The precise content of EU negotiating directives had not been previously disclosed, and could have been exploited by the EU's negotiating partners, thus establishing a risk to the EU's international relations. The Court did not discuss the fact that, unlike in the ACTA case described above, the EU's negotiating partner, the Council of Europe, had in fact placed all its negotiating directives on the internet, which should have had some effect on the need to maintain a climate of confidence. But the Court did establish that those parts of the directives which merely referred to the principles included in the EU Treaties that should govern the relevant negotiations, or the list of questions to be addressed in the negotiations, should have been handed out. The Court left the identification of these parts to the Council itself, and in January 2014 the Council finally decided that "at the present point in time, the applicant may have access to document $9689 / 10$ in its entirety" (Council, 2014, para. 5). Formally, this was justified with the passing of time and the conclusion of a draft agreement at negotiators' level (Council, 2014, paras. 4-5). The mandate is now publicly available in the Council register and it is up to anyone interested to try to identify the parts which might have fulfilled the criteria established by the Court.

\subsection{Increased Transparency in Negotiations?}

These cases have demonstrated that international relations are difficult to treat as a categorical exception. They include matters where it should be possible to consider the public interest relating to transparency, especially if the possible harm of disclosure seems limited or hypothetical. An important feature of this jurisprudence concerns the substance of these agreements. They are fundamentally important international agreements that have implications for the life of individual citizens. These concerns are also relevant when considering the Transatlantic Trade and Investment Partnership (TTIP), which is the most important of the new type of preferential trade agreements the EU has negotiated since 2006. Consequently, the need to ensure transparency has figured high on the agenda. Numerous NGOs have stressed how transparency in the negotiations needs to be ensured, 
since the TTIP would impact domestic regulations, standards and safeguards both in the US and the EU, as well as future choices in permanent regulatory cooperation (Gheyle \& De Ville, 2017). Ultimately, a failure to commit to more openness in TTIP negotiations will not only result in growing public opposition to TTIP as a whole but also create a real risk of a biased and flawed agreement (see Corporate Europe Observatory, 2017). Another example of the interest provoked by the agreement is how the Commission on-line consultation regarding the investment protection aspects of the envisaged agreement garnered approximately 150,000 replies (European Commission, 2015a). Following strong public reactions, key EU documents have been released, together with joint EU-US reports on the stage of negotiations. ${ }^{4}$ As Cremona notes, the release of information on the TTIP is remarkable, and has signalled a new approach to transparency in trade negotiations (Cremona, 2015, p. 361).

However, doubts persist. A European Citizens' Initiative (ECl) invites the European Commission to recommend to the Council to repeal the negotiating mandate for the TTIP and not to conclude the Comprehensive Economic and Trade Agreement (CETA). One of the grounds refers in particular to how key policies should not be deregulated in non-transparent negotiations. ${ }^{5}$ The matter is now pending before the General Court (Efler and others v. Commission, 2014). Following a number of complaints about the TTIP, the European Ombudsman also opened an own-initiative inquiry into the matter (see European Ombudsman, 2014a, 2014b), and subsequently set three criteria for evaluating harm in this context: disclosure would not "damage mutual trust between the negotiators; inhibit the development of free and effective discussions in the context of the negotiations and/or reveal strategic elements of the negotiations either to the other negotiating party or to third parties". These criteria would seem to exclude questions that are entirely internal to EU decision-making. Following the TTIP experience, it is likely to be difficult to roll back on transparency in other negotiations. After all:

The publication of the EU's positions at different stages of elaboration and thinking, together with openness to consultation and debate, helps to fill a gap which is becoming evident as international agreements are increasingly quasi-legislative in nature. (Cremona, 2015, p. 362)

External and internal pressure to hand out Council mandates has increased (Abazi \& Adriaensen, 2017). In March 2015, the Council decided to declassify the mandate given to the Commission two years earlier to negotiate an international agreement on trade in services (TiSA), as a response to "a growing public interest for this plurilateral agreement" (see Council, 2015; see also Council, 2013). Corporate Europe's Observatory's response to the Ombudsman's TTIP consultation lists out a serious number of international negotiating fora where greater transparency is routinely exercised (Corporate Europe Observatory, 2014). ${ }^{6}$ Many of the mandates that have been subject to transparency appeals and then subsequently disclosed-after a delay, during which negotiations have certainly advanced considerably-highlight the general nature of negotiating directives. This leaves the Commission to make the substantive choices, and should raise significant accountability issues in the context of international negotiations-issues that require democratic oversight at both EU and national levels. In fact, transparency in external relations often appears just as much as an exercise in ensuring accountability than one relating to citizen participation as such.

\section{External Logics in Internal Negotiations}

The questions relating to openness, secrecy and the possible need to ensure a negotiating space for the institutions can be mirrored against institutional practices in the internal sphere, namely the EU law-making procedures. The Court had an opportunity to interpret Article $4(3)$ in the post-Lisbon legislative context when Access Info Europe, an NGO promoting freedom of information in the EU, requested access to a legislative document that included footnotes indicating the positions of individual Member States. The central question was whether disclosure of such positions decreases the effectiveness of decision-making and if yes, which one should take priority, effectiveness or openness. The Council lost in General Court and appealed to the Court of Justice, arguing that undue and excessive weight had been attached to transparency while ignoring considerations of effectiveness (Council v. Access Info Europe, 2013). In the Council's view, identifying the delegations was not necessary for ensuring a democratic debate. The CJEU rejected this with reference to how full access can be limited only if there is a genuine risk that the protected interests might be undermined. The high standard of proof required to establish that level of harm makes it almost impossible to rely on Article 4(3) in this context. In particular, according to the Court, proposals for amendment or re-drafting made by some Member States that were described in the requested document are a part of the normal legislative process, which "could not be regarded as sensitive....by reference to any criterion whatsoever" (Council v. Access Info Europe, 2013, para. 63).

This suggests that Member States' positions in the legislative context do not merit any particular protection and are subject to full transparency, in contrast to positions in an international negotiating context that might

\footnotetext{
${ }^{4}$ See the Commission TTIP website: http://ec.europa.eu/trade/policy/in-focus/ttip

${ }^{5}$ The Commission rejected the ECI with reference to how the ECl fell outside the framework of its powers to submit a proposal for an EU "legal act". See European Commission (2014).

${ }^{6}$ These fora include the World Trade Organisation (WTO), the United Nations Framework for Convention on Climate Change (UNFCCC), the World Intellectual Property Organisation (WIPO) and the bodies under the Aarhus Convention.
} 
merit secrecy with reference to the need to achieve the Union's strategic objectives. The Court's lack of understanding for the necessity of secrecy in the internal context was something that the Council and certain Member States fiercely objected to during the Access Info proceedings, stressing also how the internal "legislative process is very fluid and requires a high level of flexibility" in order for Member States to be free to modify their positions and maximise the chances of reaching an agreement. In their view, maximum room for manœuvre for the Member States is necessary in order to ensure a "negotiating space" and thereby preserve the effectiveness of the legislative process. Identifying delegations would reduce that room for manœuvre because this would have the effect of triggering pressure from public opinion, and thus hamper the Council's decision-making process (Council v. Access Info Europe, 2013, para. 24). The Court rejected these arguments, but they illustrate how the Member States' view of the EU legislative process has not changed from the days when EU discussions were considered international negotiations and as such subject to diplomatic secrecy.

Access to legislative documents, in particular those relating to informal interinstitutional negotiations (trilogues), has become particularly topical. First, the new Interinstitutional Agreement on Better Regulation addresses the organisation of the ordinary legislative procedure in general, and the transparency of trilogies in particular (European Parliament, Council, \& European Commission, 2016, articles 32-40). Second, the European Ombudsman has recently closed a strategic inquiry concerning the proactive transparency of trilogues, stressing their role as the forum where the deals are done and the subsequent need to consider the proper trade-off between Europeans' right to open EU law-making processes and the space to negotiate. The key consideration in the inquiry was which information and documents used in the trilogue context could be made proactively available to the public, and at what point in time (European Ombudsman, 2015; Kingdom of Sweden and Maurizio Turco v. the Council, 2008, paras. 45-46). The submissions received by the European Ombudsman in the context of her inquiry from citizens, NGOs, academics and national parliaments "overwhelmingly made the case for enhanced Trilogue transparency" (European Ombudsman, 2015). Finally, there are a number of pending and recently closed Court cases relating to legislative documents generally and documents relating to the trilogue stage of negotiations more specifically. ${ }^{7}$ The pending case brought by Emilio de Capitani against his former employer, the EP, concerns especially the four-column documents used as a basis for trilogues (De Capitani v. European Parliament, 2015). In addition to the positions of the three institutions involved in the negotiations, these documents also include a fourth column indicating the emerging compromise.
Efficient law-making is largely promoted through bypassing the formal machinery of three readings and conciliation (Bunyan, 2009). Efficiency is counted through the number of closed legislative files for each Council Presidency and EP Rapporteur (Leino, 2017). Trilogues are the prime example of informal decision-making and have taken over as the main forum for making legislative deals between the three institutions (Centre for European Policy Studies High-Level Group, 2014, pp. 1-24; see in greater detail Leino, 2017). They are an efficient format for accommodating institutional positions, and have led to a great majority of deals being closed early in the legislative procedure. Their use is flexible: trilogies "may be held at all stages of the procedure and at different levels of representation, depending on the nature of the expected discussion" (European Parliament, Council, \& European Commission, 2007). During the trilogue phase, the EU democratic process is in the hands of very few: the EP rapporteur(s), the representatives of the Council Presidency and Secretariat and a few Commission officials. This phase largely escapes public scrutiny. Civil society representatives have, for very good reasons, pointed out how trilogues represent the victory of efficient law-making over transparency (see e.g. Bunyan, 2009). National parliaments often experience difficulties following decision-making in trilogues. Amendments are made at great speed, which hinders their effective scrutiny at national level (House of Lords European Union Committee, 2009, pp. 15-16).

Against this background, the recent recommendations by the European Ombudsman on enhancing trilogue transparency can be considered somewhat weak. The Ombudsman recognises a general difficulty in tracing and locating existing public information and recommends the establishment of a joint database. She urges the institutions to provide information on trilogue dates and the institutions' initial positions on the Commission proposal-something that will prove painful for the Council, whose mandates often remain confidential when adopted at Coreper level. As far as the actual trilogue negotiations are concerned, the Ombudsman asks for general summary agendas before or shortly after the trilogue meetings, but is satisfied with information that does not reveal individual strategies or compromise negotiations. She acknowledges that access to the evolving versions of the four-column document would allow the public to follow how a final text has emerged from the institutions' different starting positions. However, the European Ombudsman proves sensitive to institutional concerns relating to efficiency: "It is arguable that the interest in well-functioning trilogue negotiations temporarily outweighs the interest in transparency for as long as the trilogue negotiations are ongoing" (European Ombudsman, 2016, para. 54). Four-column documents should however be made proactively available as soon as possible after the nego-

\footnotetext{
${ }^{7}$ For closed cases, see Herbert Smith Freehills LLP v. Commission (2016); Herbert Smith Freehills LLP v. Council (2016); Philip Morris Ltd v. Commission (2016a, 2016b).
} 
tiations have been concluded (European Ombudsman, 2016, para. 56).

It is striking that these solutions are not familiar from the legislative context but from the Court jurisprudence and recent practices adopted in relation to international regulatory agreements. In relation to both, sufficient transparency is believed to be guaranteed through the publication of initial positions. Transparency during negotiations is reduced to communication with reference to considerations of efficiency. While in the broader context of international affairs this sort of solution might provoke celebration, in the legislative context, however, this is hardly a satisfactory solution.

\section{Conclusion}

This paper showed that categorical solutions relating to transparency or secrecy, or dichotomies based on a strict division between "internal" and "external", are fundamentally outdated. A more political debate is needed on the way in which the exercise of democratic rights can be effectively exhausted. In practice this often takes place through the choices of technocrats in the EU institutions addressing requests by individual citizens. The arguments used by the institutions to defend secrecy gives reason for some concern, since it reflects an understanding that is not responsive to openness and prioritises the internal efficiency of the institution's own work. A new understanding of "harm" and the importance of openness in legitimate governance would need to be introduced into institutional thinking. It is exactly this angle that has been repeatedly voiced by civil society organisations in the context of both internal and external negotiations. The challenge relates to an overly broad use of exception grounds, something that the Courts have frequently pointed out. These cases represent only a minor part of the negative decisions adopted by the institutions, but the argumentation used in them provides insights into how they reason. The rationale of openness and transparency should not be too focused on accountability or deliberation when legislative acts are adopted, but should speak to a corresponding need of public involvement in international affairs. This would seem to be exactly the point raised in the Laeken Declaration quoted in the beginning of the paper: more efficient, but at the same time more open, and more democratically accountable.

\section{Acknowledgments}

I thank Emilia Korkea-aho, Liisa Leppävirta and Olli Mäenpää for useful discussions around the theme.

\section{Conflict of Interests}

The author declares no conflict of interests.

\section{References}

Abazi, V., \& Adriaensen, J. (2017). Allies in transparency? Parliamentary, judicial and administrative interplays in the EU's international negotiations. Politics \& Governance, 5(3), 75-86.

Abazi, V., \& Hillebrandt, M. (2015). The legal limits to confidential negotiations: Recent case law developments in Council transparency: Access Info Europe and In't Veld. Common Market Law Review, 52, 825-846.

Bradford, A. (2012). The Brussels effect. Northwestern University Law Review, 107(1), 1-67.

Bunyan, T. (2009). European Parliament: Abolish 1st [and 2nd] reading secret deals-Bring back democracy "warts and all". Statewatch. Retrieved from http://www.statewatch.org/analyses/no-84-ep-firstreading-deals.pdf

Centre for European Policy Studies High-Level Group. (2014). Shifting EU institutional reform into high gear. Centre for European Policy Studies. Retrieved from https://www.ceps.eu/publications/shifting-euinstitutional-reform-high-gear-report-ceps-high-level -group

ClientEarth v. Commission, Case T-424/14, EU:T:2015: 848 (2015).

Corporate Europe Observatory. (2014). TTIP talk: CEO's response to Ombudsman's consultation on transparency. Corporate Europe Observatory. Retrieved from https://corporateeurope.org/international-tra de/2014/10/ttip-talks-ceo-response-ombudsman-con sultation-transparency

Corporate Europe Observatory. (2017). International trade. Corporate Europe Observatory. Retrieved from https://corporateeurope.org/international-trade

Council. (2013). Draft directives for the negotiation of a plurilateral agreement on trade in services (6891/13 ADD 1 DCL 1). Brussels: Council of the European Union.

Council. (2014). Revised reply to confirmatory application No 04/c/01/11 following the judgment of the General Court in Case T-331/11. (5022/14). Brussels: Council of the European Union.

Council. (2015). Press release: Trade in services agreement: negotiating mandate made public. Council. Retrieved from http://www.consilium.europa.eu/en/ press/press-releases/2015/03/150310-trade-services -agreement-negotiating-mandate-made-public

Council v. Access Info Europe, Case C-280/11 P, EU:C: 2013:325 (2013).

Council v. Sophie in't Veld, Case C-350/12 P, EU:C:2014: 2039 (2014).

Cremona, M. (2015). Guest editorial: Negotiating the Transatlantic Trade and Investment Partnership (TTIP). Common Market Law Review, 52, 351-362.

Curtin, D. (2009). Executive power in the European Union. Oxford: Oxford University Press. 
Curtin, D. (2012). Judging EU secrecy. Cahiers de Droit Européen, 2, 459-490.

Curtin, D., \& Leino, P. (2016). Openness, transparency and the right of access to documents in the EU. In-depth analysis (Robert Schuman Centre for Advanced Studies Research Paper No. RSCAS 2016/63). Retrieved from https://papers.ssrn.com/sol3/papers. cfm?abstract_id=2879315\#\#

De Capitani v. European Parliament, Case T-540/15 (2015).

Efler and others v. Commission, Case T-754/14 (2014).

European Commission. (2014). Commission decision of 10 September 2014 on the refusal to register the European Citizens' Initiative 'Stop TTIP' (C(2014) 6501 final). Brussels: European Commission.

European Commission. (2015a). Report presented today: Consultation on investment protection in EU-US trade talks. European Commission. Retrieved from http://trade.ec.europa.eu/doclib/press/index.cfm? id $=1234$

European Commission. (2015b). Management plan 2015 Directorate General internal market, industry, entrepreneurship and SMEs (DG growth) (Ref. Ares(2015)3738909-10/09/2015). Brussels: European Commission.

European Council. (2001). Presidency conclusions, European Council meeting in Laeken, 14 and 15 December 2001. Retrieved from http://ec.europa.eu/smartregulation/impact/background/docs/laeken_concl_ en.pdf

European Ombudsman. (2010). Decision of the European Ombudsman closing his inquiry into complainant 90/2009/(JD)OV against the Council of the European Union. Strasbourg: European Ombudsman.

European Ombudsman. (2013). Decision of the European Ombudsman in his inquiry into complaint 2393/2011/RA against the European Parliament. Strasbourg: European Ombudsman.

European Ombudsman. (2014a). Letter to the Council of the $E U$ requesting an opinion in the European $\mathrm{Om}$ budsman's own-initiative inquiry OI/10/2014/MMN concerning transparency and public participation in relation to the Transatlantic Trade and Investment Partnership (TTIP) negotiations. Strasbourg: European Ombudsman.

European Ombudsman. (2014b). Letter to the European Commission requesting an opinion in the European Ombudsman's own-initiative inquiry Ol/10/2014/MMN concerning transparency and public participation in relation to the Transatlantic Trade and Investment Partnership (TTIP) negotiations. Strasbourg: European Ombudsman.

European Ombudsman. (2015). Decision in case 904/2014/OV on the European Commission's public consultation prior to its legislative proposal for a Regulation concerning the European single market for electronic communications. Strasbourg: European Ombudsman.
European Ombudsman. (2016). Decision of the European Ombudsman setting out proposals following her strategic inquiry OI/8/2015/JAS concerning the transparency of dialogues. Strasbourg: European Ombudsman.

European Parliament. (2010). Written declaration pursuant to Rule 123 on the Rules of Procedure on the lack of a transparent process for the Anti-Counterfeiting Trade Agreement (ACTA) and potentially objectionable content (0012/2010). Brussels: European Parliament.

European Parliament, Council, \& European Commission. (2007). Joint declaration on practical arrangements for the codecision procedure (article 251 of the EC Treaty), OJ C145/5. Brussels: European Union.

European Parliament, Council, \& European Commission. (2016). Interinstitutional agreement of 13 April 2016 on better law-making, OJ L123/1. Brussels: European Union.

European Parliament \& European Commission. (2010). Framework agreement on relations between the European Parliament and the European Commission, $O J$ L304/47. Brussels: European Union.

Gheyle, N., \& De Ville, F. (2017). How much is enough? Explaining the continuous transparency conflict in TTIP. Politics \& Governance, 5(3), 16-28.

Herbert Smith Freehills LLP v. Commission, Case T755/14, EU:T:2016:482 (2016).

Herbert Smith Freehills LLP v. Council, Case T-710/14, EU:T:2016:494 (2016).

House of Lords European Union Committee. (2009). Codecision and national parliamentary scrutiny (17th Report of Session 2008-09). Retrieved from https://publications.parliament.uk/pa/ld200809/ld select/ldeucom/125/125.pdf

Kingdom of Sweden and Maurizio Turco v. Council, Joined Cases C-39/05 P and C-52/05 P, EU:C:2008: 374 (2008).

Leino, P. (2011). Just a little sunshine in the rain: The 2010 case law of the European Court of Justice on access to documents. Common Market Law Review, 48(4), 1215-1252.

Leino, P. (2014). Transparency, participation and EU institutional practice: An inquiry into the limits of the 'widest possible' (EUI Working Papers LAW 2014/3). Retrieved from http://cadmus.eui.eu/handle/1814/ 30580

Leino, P. (2017). The politics of efficient compromise in the adoption of EU legal acts. In M. Cremona (Ed.), EU legal acts: Challenges and transformations, collected courses of the academy of European law. Oxford: Oxford University Press.

Leino, P. (in press). The principle of transparency in EU external relations law-Does diplomatic secrecy stand a chance of surviving the age of twitter? In M. Cremona (Ed.), Structural Principles in EU external relations law. Oxford: Hart Publishing.

Leonard Besselink v. Council, Case T-331/11, EU:T:2013: 419 (2013). 
Macmillan, M. (2011). A short history of secrecy. Foreign Policy. Retrieved from http://foreignpolicy.com/ 2011/02/21/a-short-history-of-secrecy

Mendes, J. (2015). The EU and the international legal order: The impact of international rules on EU administrative procedures. Notes for the JURI Committee in the European Parliament. Retrieved from http:// www.europarl.europa.eu/cmsdata/72869/Mendes. pdf

Novak, S. (2011). Is there a tension between transparency and efficiency in decisions? The case of the Council of the European Union. Florence: European University Institute.

Philip Morris Ltd v. Commission, Case T-796/14, EU:T: 2016:483 (2016a).

Philip Morris Ltd v. Commission, Case T-18/15, EU:T: 2016:487 (2016b).

Schlyter v. Commission, Case T-402/12, EU:T:2015:209 (2015).

\section{About the Author}

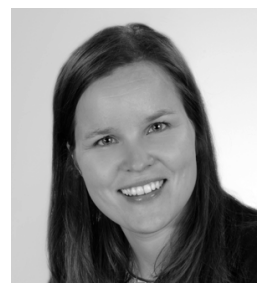

Päivi Leino is Professor of International and European Law at UEF Law School, Adjunct Professor of EU Law at the University of Helsinki, Academy of Finland Research Fellow and Visiting Fellow at the EUI Law Department. She currently leads two research projects on transparency and participation in EU decision-making funded by the Academy of Finland. She has previously worked as legal counsellor for the Finnish government (2005-2015) participating in various international and EU negotiations.
Scott, J. (2014). Extraterritoriality and territorial extension in EU law. American Journal of Comparative Law, 62, 87-125.

Sison v. Council, Case C-266/05 P, EU:C:2007:75 (2007). Sophie in 't Veld v. Commission, Case T-301/19, EU:T: 2013:135 (2013).

Sophie in 't Veld v. Council, Case T-529/09, EU:T:2012: 215 (2012).

Verein für Konsumenteninformation v. Commission, Case T-2/03, EU:T:2005:125 (2005).

Waxman, H. (2004). The chemical industry, the Bush Administration, and European efforts to regulate chemicals. Washington, DC: US House of Representatives Committee on Government Reform.

Westlake, M., \& Galloway, D. (2004). The Council of The European Union. London: John Harper Publishing. 